\title{
Article \\ Humble Hopes in Mentorship and Education: Thinking with Temporality
}

\author{
Bente Ulla *(D) and Ann Sofi Larsen*(D) \\ Department of Education, ICT and Learning, Østfold University College, N-1757 Halden, Norway \\ * Correspondence: bente.ulla@hiof.no (B.U.); ann.s.larsen@hiof.no (A.S.L.)
}

\begin{abstract}
This article juxtaposes mentoring with an extended concept of time, arguing against the idea of mentoring as a unilaterally forward-moving progression. We discuss how time and temporality unfold in mentoring in the teaching profession. We further explore how temporality might create different potentialities of hope. Ultimately, we suggest the necessity of destabilising narratives of mentoring as constant and linear improvements. We use an example of an inheritance from the past as an analogy in order to provide a thematic starting point for our discussion. This example supports the exploration of how mentorship programme assignments are experienced as well as how conversations are constantly filtered through time. The article builds on the empirical elements of a study of a mentorship programme to explore potentialities that are of importance in mentorship and education.
\end{abstract}

Keywords: mentorship; temporality; aion; ontology; liminal moment; inheritance; humble hope

Citation: Ulla, B.; Larsen, A.S.

Humble Hopes in Mentorship and

Education: Thinking with

Temporality. Educ. Sci. 2021, 11, 635.

https://doi.org/10.3390/educsci

11100635

Academic Editor: Anne

Beate Reinertsen

Received: 4 August 2021

Accepted: 11 October 2021

Published: 13 October 2021

Publisher's Note: MDPI stays neutral with regard to jurisdictional claims in published maps and institutional affiliations.

Copyright: (c) 2021 by the authors. Licensee MDPI, Basel, Switzerland. This article is an open access article distributed under the terms and conditions of the Creative Commons Attribution (CC BY) license (https:// creativecommons.org/licenses/by/ $4.0 /)$.

\section{Introduction}

This article utilises temporality as a conceptual lens to explore experiences of time in mentoring programmes in the teaching profession. Through a larger narrative concerning movements in time, we challenge mentoring as a unilaterally forward-moving progression, thus searching beyond a one-dimensional future. In order to address the complexities involved, this article elaborates upon Jacques Derrida's [1] concept of inheritance and, further, his notion of paradoxes unfolding in the future. Derrida explores an irregular future, which bears both continuity and discontinuity, maintaining expectations of predictability while simultaneously calling for the unknowable. Times gone by are not merely located in the past; they do not simply things that are now completed. This is of importance to recognise when mentors connect with mentees and work on formulating, de-formulating and re-formulating, processes through which they think, feel and doubt together. They orient, value and listen to each other and the stories explored. The conversations become filtered through time. The stories that are shared always bring with them new potentialities of the past, the present and the future. With this in mind, allow us, for a moment, to introduce an anecdote to provide a thematic starting point.

\subsection{Grandmother's Bequest}

I inherited a tea service set. It has been several years since my grandmother left the tea set to me. It is pretty-white with a pattern of blue flowers. My grandmother collected the tea set over the years, gathering cups, saucers and plates on birthdays, Christmases and other special occasions. Altogether, there are 12 cups, 12 saucers, 12 tea plates and a sugar bowl. The tea service is now stored in a kitchen cupboard. I rarely use it. I cannot remember when I last set the cups and plates out for a meal. Yet, the tea service still speaks to me of a history that is greater than culinary experiences. I inherited something more than crockery; it is something that accompanies me when we are gathered around the table, even when we are gathered in new ways. I carry my past into new becomings. 


\subsection{Aim and Structure}

This 'Grandmother's bequest' enables us to become aware of how time does not transpire as a linear movement. The bequest helps us to meander the nuances of inheritance and temporality, where matter and memories continue to unfold in a relational field. This article aims to explore how mentors in teaching professions work across sophisticated premises of time and liminal moments, and further, how temporality creates different potentialities of hope.

Firstly, we begin with a brief outline of the governmental investment in education and mentoring programmes for teachers in Norway and further connect this to the field of early childhood education and care. We outline these contextual factors in order to present them for disputation, renewal and change. Next, we outline temporality through philosophies of difference to provide a theoretical tool to rupture both the well-established linear timeline and notions of pedagogical development and progression. In order to avoid separating what has been from the present and the future, the concept of inheritance is introduced as a process which enables the development of an intricate connection between time and becoming. The article then moves onto an empirical section, where narratives from mentors are presented. The narratives were written by early childhood teachers during their in-service programme for mentorship training. From this point forward, we refer to them as mentors. While they participated in the programme, we asked them to submit logs concerning their experience of becoming mentors. Without claiming to propose a path to hope, the article concludes by emphasising that thinking with temporality might present potentialities of humble expectations.

\subsection{Contextual Fields}

In recent decades, there has been substantial level of governmental investment in education and mentoring programmes for teachers in Norway [2]. Mentoring is considered to be an important element through which early childhood teachers can develop pedagogical knowledge and a professional identity [3]. Moreover, Norway's early childhood education curriculum [4] emphasises mentoring as a key factor in pedagogical leadership. Mentoring requires widening and challenging perspectives in terms of values and norms towards teaching and learning and towards what is, or might become, knowable. In the government's guidelines, mentors are tasked with the responsibility to play a key role in the organisation of learning, a task highlighted in the curriculum. Such a task requires generating questions beyond those related to structures, frameworks and models for mentoring.

Several researchers have highlighted the temporal aspects of mentoring, problematising issues pertaining to the idea of mentoring as a continuum during the process of transitioning from primary education to adopting mentoring as a professional practice [5-9]. Other researchers have emphasised the relationship between the individual and collective dimensions of mentoring, thus problematising the common belief that mentoring is individual, isolated and instrumental and, therefore, reduced to routine techniques [10-14]. Overall, the significant task of expanding mentorship beyond routine techniques related to separate individuals has been emphasised, and the idea of promoting continuums in mentorship has been questioned. In previous articles, we have argued for expanding the theoretical and philosophical basis for mentoring [15-17]. As a supplement to this contemporary research, this article seeks to expand temporal aspects by exploring connections between multiple layers of time in mentorship. A specific connection to hope arises as we endeavor to think using temporality. The next section discusses the concept of temporality in order to ground it within an ontological and epistemological framework.

\section{Temporality: Crossing Movements}

We adopt the stance that mentoring is intrinsically related to questions concerning 'the ontologically slippery nature of time' [18] (p. 513). Slipperiness expands time beyond fixedness; it moves time into unsteadiness. Time becomes an open system, which includes 
the unknowable and unpredictable. When we take this movement across time into account, we become aware that the transformation towards the future does not take place as a linear movement. Indeed, Elizabeth Grosz [19] emphasises this very idea:

Yet the being of time is this very peculiar becoming which touches all things with its directed movement forward to the future while always looping relentlessly back over the past, always carrying and transforming the past as it transforms itself to give way to the future. (p. 142).

In the context of mentoring, this crossing movement affects how the mentor and mentee relate the issues discussed in the mentoring programme to the traditions and knowledge base of the profession itself while still engaging in critical thinking $[17,20,21]$. Practicing mentorship presents greater potentialities than simply adjusting to contemporary demands. In this way, time, place and relationships can enact change that extends beyond linear and forward movements. This change transcends beyond focusing on consistency, a presence and an assessment of that which is reliable here and now.

By focusing attention on the epistemological and ontological notions of temporality, we respond to what Joce Nuttall and Louise Thomas [18] underline as crucial to early childhood teachers' work. We respond to their request and account for the importance of time beyond its use as an objective resource. Our intention is not rooted in a desire to stabilise time nor to reconfigure ecologies of time in a particular way-to see the future 'as the prolongation of the present' [22] (p. 337) -rather, we speculate on how to elaborate on the traditional system of time. The purpose is to connect mentorship with questions of temporality and to include temporal aspects when focusing on the possibility to create, live and learn together through mentorship. What we undertake here is a nomadic movement of being and becoming. Thus, processes of transformation, subjectivation and temporality are interconnected. In other words, we are not isolating mentorship to epistemological questions but addressing it as a highly ontological issue [17].

\subsection{Temporality and Modes of Possibilities}

Epistemological and ontological questions require a conception of time that work beyond the mere chronological organisation of events. In everyday speech, when we discuss the allocation of time for mentoring, we are referring to a chronological timeline. An extended approach to time allows us to question the mechanical presentations of time derived from clocks. Additionally, it expands our opportunities to challenge the very notion of the mechanical organisation of time. Indeed, further nuances arise when we notice how time is divided and organised into segments, including in the structure of a mentoring programme. Linearity is at the heart of the Western time system, with chronology repeating itself day after day, year after year.

The mechanical presentation of time is accepted and integrated as a part of everyday life; it is a system of inherited orders with which we are familiar. It may be, for example, that the programme allocates time for mentoring every other Thursday between ten and eleven o'clock in the morning. It may be difficult to accept that this system is not inevitable. After all, we go to bed in the evening and wake up and begin a new day. One hour is followed by the next. There are certain inevitable questions one might ask an early childhood teacher, for example, 'How many years of teaching experience do you have?' Aspects of time are seen even in political guidelines that regulate the offering of mentorship programmes to newly qualified teachers [23]. Those who are defined as newly qualified teachers are in their first two years as teachers. The years are counted, time is organised and chronologies circulate. Indeed, the chronological measurement of time can even be helpful in tasks related to time management.

If our lives are not guided only by chronological time, it becomes significant to not only enhance time itself but also broaden our understanding of ourselves: we, you, the mentee and the mentor, altogether, of who we are in time, and of who we become. We draw upon the work of Rosi Braidotti [24,25] to increase the awareness of the processes of being and becoming beyond fixedness. Being and becoming relate to a nomadic movement. Let 
us therefore turn to Braidotti's [25] nomadic subject, closely interwoven with the unsteady balance of time:

Remembering in this nomadic mode is a key element of this process. Virginia Woolf's work reflects admirably the dual structure of time: the linear oneChronos-and the undifferentiated one-Aion. Being and Becoming confront each other in an unsteady balance. (p. 173).

Aion opens another layer of time: a mode of possibilities. Braidotti suggests that the subject is a generative one in a constant state of becoming. A multi-layered and unsteady approach to time might be essential in to developing critical assessments of the dominant calls for securing the future. The early childhood teachers who have accepted the responsibility that is entailed by becoming mentors are being asked to document and report, by 'planning, implementing, documenting, assessing and developing' [4] (p. 16) for pedagogical development. The governmental guidelines cross time perspectives, but the crossover is primarily directed forwards-it centres on the future. When the mentors and the mentees assemble, they work beyond individual and isolated obligations concerned with developing knowledge for the future. They work through interwoven moments of past, present and future, moving towards fundamental questions regarding conditions for being and becoming. Movements of being and becoming challenge them to persevere through processes of unsteadiness and fluidity.

\subsection{Inheritance as a Task}

Let us try to unfold the concept of inheritance and further move into the landscape of temporality related to mentorship in the teaching profession. The Grandmother's bequest enables us to become aware of how matter and memories continue unfolding into nuances of inheritance and temporality. Drawing from Derrida [1], the concept of inheriting is defined as something greater than the transferring of physical objects from generation to generation. Indeed, he helps us to understand inheriting as a task that is never assumed. Being and inheriting form an intricate relationship that combine in an ontological field:

All the questions about being or of what is to be (or not to be) are questions of inheritance. [...]. That we are heirs does not mean that we have or that we receive this or that, some inheritance that enriches us one day with this or that, but that the being of what we are is first of all inheritance, whether we like it or know it or not. [...]. we inherit the very thing that allows us to bear witness to it [1]. (pp. 67-68).

Considering this quote, the grandmother's bequest becomes more than a beautiful tea service that has been received as a gift. The inheritance consists of more than beautiful objects. The tea service is accompanied by memories of people, events and feelings that also become inheritances. The temporal defers to a process of constant delay and change, challenging our perception of the present as unchangeable $[1,26]$. The foreseeable, in contrast with the unpredictable, can enter the present unexpectedly and at any moment. Hoy [27] provides the formula of temporalisation that Derrida is looking for: 'What is now present to us is the past of a future present' (p. 172). Understandings, including the understanding of time, are never quite immediate, but are also created through things that are absent, by things that are not present but, nevertheless, still affect [26]. Temporality brings us once more to the narrative regarding a grandmother and the traces that remain after her death. The tea service in the cupboard, the clock on the desk, the photograph of her in her youth, her handwritten recipes and small notes and the memory of her voicethese are the traces that disconnect the sense and experience of time from actual temporal presence/absence.

Grosz [28] helps further locate our curiosity in the connections between time and becoming: 
The present is that which acts and lives, which functions to anticipate an imme-

diate future in action. [...]. The past is that which no longer acts, although in a sense it lives a shadowy and fleeting existence; it still is, it is real. (p. 102).

Grosz offers an approach that allows us to discover eternities beyond linear time [19,28]. Moreover, she describes the distinctions between time and the things that exist in time: "What recycles, is never time itself but what exists in time: things, processes, events, formations, constellations, in short, matter in all its permutations" [19] (p. 142). If we transfer these distinctions into the context of mentorship and teaching, a space presents itself that accommodates for a broader awareness of ideas about time.

\section{The Mentors' Logs: What Are We Hurrying to Reach?}

As previously mentioned, students in an in-service programme for mentorship training were asked to write logs documenting their experiences of becoming mentors while they practiced mentoring in their own workplace during the mentor programme. The mentors were not asked to write specifically about time. Instead, they were encouraged to write exploratively about their experiences during mentoring. While closely reading their logs, we became aware of how various manifestations of time present themselves. Further, we noticed how time and temporality unfolded in their reflections on mentoring. In the following section, we bring in four extracts from the logs. Using temporality as a lens, we analyse how various aspects of time might unfold before we further advance the discussion into landscapes of hope. Instead of marking the different extracts as Mentor 1, 2 or 3 , we present them as elements of a compound narrative.

\subsection{Coming out of Step with Speed}

In the following extracts, we have selected descriptions of pauses. The extracts make us aware of how the mentor manoeuvres as she eases her tempo, orienting towards a stretch of silence in the session:

Extract from Log: During the mentoring sessions that I have carried out recently I have also experienced pauses. [...]. Pauses in which the person being mentored had a good deal of time to think, and I as mentor felt my own inner unease.

The mentor writes about an inner unease taking place, in which she describes the stretch of silence as an opportunity to think. Her description indicates that the duration of a pause is experienced differently by the mentor and the mentee. This excerpt demonstrates a sensed or experienced time. Here, the mentor touches upon what Nuttall and Thomas [18] describe as 'the material nature of temporality. [...]. allowing individuals to orient their bodies in space and time' (p. 520). The moment in which the mentor slows down is not experienced one dimensionally. Instead, the moment begins to unfold as an asynchronous timepiece. The feeling of unease hints at discomfort. Yet, she chooses to stay with the silence. She ventures the pause in her retrospective writing, but she does not present the moment as straightforward. Her writing informs us of a sensed silence that is 'felt not only in the body but in the ebb and flow of multiple bodies across space and time' [18] (p. 520). The mentor is in the process of becoming asynchronous with the programme's schedule:

Extract from Log: What are we hurrying to reach? What is it about time? [...]. It is rarely that there is not some point in the mentoring where the tempo is too fast. I have noticed this several times and used meta-communication together with the person being mentored to reduce the tempo and to ensure that we are on their path.

Despite identifying a risk of dissonance, she to defies the expectations of tempo. She asks herself where the expectations of rapidity might originate. Although she does not identify an external source of the expectations, she describes rapidity as a subtle demand throughout her log. She resumes with new questions as she dwells on the tempo of the mentoring conversation. Hastening to reach something is understood to be the result of a set, linear timescale and the existence of constant pressure for completion. An 
extension is, however, suggested through the question that she raises about what it is that they are attempting to reach. This line of questioning introduces disorder and a set of disturbing rhythms that disrupt the linear notion of time. She creates a terrain whereby time can accommodate new rhythms and variety. The mentor experiences time subject to variation, irreversibility and discontinuity. She offers alternatives to presenting tempo as a consistent beat.

\subsection{Denting a Chronological Timeline}

The mentor's questions interrupt the session's chronological timeline. Alternative ways of practicing mentorship emerge amid this interruption in speed. This adjustment takes form during the pause, but the mentor draws awareness to the pause as not simply an absence of activity. Instead, she explores the pause as a form of continuing activity-a quiet interlude in the conversation. She does not regard herself as outside of time/place but allows herself to consider what the deceleration offers. The mentor continues her description of how her reflections altered during the conversation:

Extract from Log: The silence. If we talk about it, and offer reassurance that there are no right and wrong reflections, then I have noticed that there becomes room for peace and silence in the mentoring conversation.

In this extract, the mentor encounters alternative modes of thinking. The silence is associated with reflection, which, in turn, is associated with opportunity for peace. We read the mentor's focus on quietness during the conversation as a way in which to highlight temporality. As she makes a slow leap to disrupt rapidity, she is located within a diachronous movement. The clock is no longer the dominant authority in the conversation and the session.

\subsection{Well-Rooted and Unsteady}

Stability is set in motion as mechanical time is no longer dominant. In the following statement, the mentor describes an experience that suggests a feeling of stepping out of time, or, more specifically, a feeling of working incongruently with time:

Extract from Log: I felt that I was being well-rooted in the situation. Time and place were forgotten, and I was not really affected by things around me. At times I was 'too' well-rooted, if that is possible to say. I became too 'swallowed up' in certain things, which meant that I was a little stuck, a little unsteady. [...]. I did not see this at the time but realised afterwards. What is it that actually happens with being well-rooted in the situation when you forget everything around you?

Losing one's sense of time is not presented as an escape from responsibility but can be regarded as valuable in mentoring [29], involving both nearness and distance in relation to who we are and who we become. It is thus not a question of avoiding the current context or the future; it is a matter of how we repeatedly stand within it.

The mentor discusses relationships that create an intense immersion in time and place. Moreover, this extended narrative does not begin to emerge until she leaves the session. Retrospectively, she describes how the intensity of the situation makes accessible several dimensions in time. She also discovers a dimension of time and space that affects the conversation between her and the person being mentored. She asks herself: 'What is it that actually happens with being well-rooted in the situation when you forget everything around you?' The intensity of the conversation shatters her intention to remain in control of the passing of time. In her log, she demonstrates her attitude to the dilemma, pointing out that the dilemma is multifaceted. She acknowledges that the feeling of being rooted entails a feeling of being trapped. Moreover, she describes herself as unsteady. Finding oneself in a multifaceted moment in time creates unsteadiness. Being unsteady speaks on movement and displacement, as well as to the splintering and disconnecting in the conversation itself. The extract from the mentor's log demonstrates how the mentor enters new and unsuspected directions in the conversation, with temporality forming the 
landscape through which the session moves. The descriptions in the log reveal nuances relating to being in time that are of importance to the mentor.

\subsection{Multiple Layers of Chronos and Aion}

The mentors wrote about their well-planned sessions and the idea of progression in their logs. By searching beyond a chronological timeline, we do not reject planning and progression. On the contrary, we invite nuance. We are curious about how the variations occurred in the mentors' descriptions of what took place. As well as planning and progression, their logs contain traces of less synchronous timepieces and a sense of unsteadiness in their perceptions of time. In the previous section, we included a mentor's log that describes a sense of unsteady balance. An inference of staggering assists us in discovering and valuing the multidimensional and multidirectional variations of experiencing temporality during the sessions. The mentor is responsible for encountering alternative opportunities for thinking, not only as she schedules the session but as she constantly readjusts and critically examines the time of becoming - the Aion or the liminal moment-'free of content, which is shot through with vibrations of becoming' [24] (p. 173). In other words, she activates multiple layers of resonance in the continuum between Chronos and Aion [24,25]. As the mentor and the mentee close the door behind them, sit down and peek at the wall clock, they attune themselves both to Chronos and Aion. They live and feel a much more sophisticated time than the seconds ticking by may ever account for. Different speeds, a pause and a perception of silence, all offer a break in the linear modes of Chronos, leading towards more nomadic expansions of time. We noticed that in the present, the mentor discovers an absence of moving forward. Still, she continues moving. The nomadic subject is closely interwoven with the unsteady balance of time. The mentor, the mentee, the speed, the pause, the silence and the broken chronological timelines are entangled in ways that present a nomadic growing timeline. In her writing on the present, Braidotti [25] suggests:

The force of the present-and the core of its intelligibility-is that it does not coincide completely with the here and now. Such synchronization is never complete, because. [...]. all human and non-human entities are nomadic subjectsin-process, in perpetual motion. (p. 36).

The force of the slippery task of becoming—of being/inheriting—is in perpetual motion. The subject is always in a process of becoming, i.e., they are the nomadic subjectin-process, the nomadic mentor-in-process and the nomadic mentee-in-process. Braidotti explores the subject-in-becoming as being both rooted and in flow. In relation to the mentor describing herself as 'too well-rooted', the work of Braidotti [24] helps us to become aware of another layer of hope. A subject-in-becoming is working to reinvent, to re-energise, and to become 'swallowed up', creating a passage to defy linearity: 'When you remember to become what you are-a subject-in-becoming-you actually reinvent yourself on the basis of what you hope you could become, with a little help from your friends' [24] (p. 173). As we read the logs, we realised that there is an attentive approach in the trainee mentors' progression towards becoming qualified mentors. By averting our gaze from a chronological linearity, we discover the shadowy places of time in the unsteadiness of temporality. The multidimensional movement of time can be valued as a gateway through which to moderate purely forward-looking perceptions of time that prioritise progression and continuity above all else.

\section{Becoming Humble Hopes}

In the following sections, we push the concept of temporality further and discuss how these various aspects of temporality also might unfold into landscapes of hope. Even though the mentors never mention hope explicitly, their narratives relate to a force reliant upon hope. As the mentors wrote their logs, they were creating and practicing a reconsideration of what they value, witness and know. They confronted an unsteady balance as they discussed who they are and simultaneously, who they sought to become. The 
conversations vary between remembering and reinventing, creating a crossing movement between what has been, what is and what might become.

We also locate time in liminal moments when the mentor draws her breath, pauses or turns her attention across fields of attendance. The crossing movement of time is embodied as the tongue rests and breathing becomes present. The mentors' logs demonstrate how the processes of mentoring travel into transversal fields of temporality. Speed becomes confronted with slowness. Talk is confronted with silence. At some point, remembering is confronted with forgetting. If we accept these confrontations as productive creations in all its permutations, it may give rise to further nuances regarding the future that Derrida [1] (p. 522) considers to be unknowable and therefore reliant upon hope. As we search to explore how the notion of temporality is entangled in the landscape of hope, it reminds us of the multi-layered past, present and future taking place even when the mentor draws her breath and takes notice of the silence in the conversation.

The multidimensional and multidirectional variations of experiences of temporality do not offer a recipe for a correct method of mentoring. However, these variations provide new strengths to cope with the uncertainties that instantly creep in during the mentoring sessions. These uncertainties parallel the distinction between a future that is predictable and a future that is unknowable. Anne Dufourmantell [30] also underlines complex images of the future by questioning how hope can become possible. She further stresses that the concept of hope might be a troubling issue because hope often encourages us to focus on a resolvable - or better-future. As Dufourmantelle [30] critically underlines:

Hope is a strange form of renunciation because it incites us to bet on the future; it offers an exit door out of the present situation and signifies to us: tomorrow will bring relief. [...]. As the secret motor of our renunciations, hope is what permits us to hold on. (p. 101).

As we explore how temporality is entangled with hope in mentorship and education, we are reminded of the multi-layered past, present and future. By utilising the narratives provided by the mentors, and with guidance from Duformantell, it becomes possible to explore hope without either becoming distracted by notions of nostalgia or becoming preoccupied with simply emerging into a better future. Dufourmantelle [30] suggests that we 'need another word for the sort of hope that despairs of the future and refuses to wait, a new type of courage' (p. 102). This form of hope will not be directed towards a resolvable and secured future. Instead, it will be an instant and humble hope-a hope that refuses to wait for the future. Dufourmantell's concept of a new hope aligns with the mentors' writing when they underline the presence of evanescence. By looking towards questions of epistemology and ontology, hope also relates to processes of active displacement. Hope presents variations of knowing and not knowing, of being and becoming. Hope becomes present and distanced in instant and humble modes. Even though the mentor manoeuvres in a context dominated by demands for a secure future, an unsteady balance of time becomes significant. We resonate with the question set forward by one of the mentors: What are we hurrying to reach? Moreover, if time is not to be managed, who are we in time? A pause, a thought, a breath and a feeling, take forms as liminal moments in the sessions, producing spaces of movements.

\section{Closing Comments}

Early childhood teachers have a responsibility to work through mentoring to widen and challenge teaching and learning as well as the relationships and histories of which they are a part. Taking this into account, mentoring is not to be reduced to an epistemological engagement. An awareness of a nomadic being and becoming expands mentoring into highly ontological issues.

As the mentor and the mentee discuss, formulate, de-formulate, re-formulate, think, feel, question and listen, they create an opportunity to not only relate to knowledge but also to the unknowable-and beyond. They struggle with questions of how it is possible to create, live and learn together. As we see it, mentorship, where the mentor and the mentee 
share, reflect on and together enhance their professional knowledge and their heritage, is a part of re-orientation. If our state of being in the world is not a given, then mentorship in the context of early childhood education may create an opportunity to hold off certainties, suspending questions and allowing hope to take form across time.

Author Contributions: All authors contribute equally to the manuscript. All authors have read and agreed to the published version of the manuscript.

Funding: This research received no external funding.

Institutional Review Board Statement: Not applicable.

Informed Consent Statement: The course was the Mentoring for Practice Teachers in Kindergarten (30etc.) is run by Østfold University College, Norway. The students were informed about the study and gave their active consent for their logs to be used in further analyses and publications. This project adheres to the guidelines of the Norwegian Centre for Research Data (NSD).

Data Availability Statement: Not applicable.

Conflicts of Interest: The authors declare no conflict of interest.

\section{References}

1. Derrida, J. Specters of Marx: The State of the Debt, the Work of Mourning and the New International; Kamuf, P., Translator; Routledge: London, UK, 2006.

2. Rambøll Management. Veiledning av nyutdannede Barnehagelærere og Lærere: En Evaluering av Veiledningsordningen og Veilederutdanningen; Rambøll Management: Oslo, Norway, 2016.

3. Shanks, R.; Tonna, M.A.; Krøjgaard, F.; Paaske, K.A.; Robson, D.; Bjerkholt, E. A comparative study of mentoring for new teachers. Prof. Dev. Educ. 2020. [CrossRef]

4. Ministry of Education and Research. Framework Plan for Kindergartens: Contents and Tasks; Ministry of Education and Research: Oslo, Norway, 2017.

5. Østrem, S.; Hansen, B. Videreutdanning i veiledning for lærere: Rasjonalitet og kontinuum [Mentor education for teachers: Rationality and continuum]. Uniped 2018, 41, 106-119. [CrossRef]

6. Bjerkholt, E. Profesjonsveiledning. Fra praktisk Virksomhet Til Teoretisk Felt; Cappelen Damm: Oslo, Norway, 2017.

7. Smith, K.; Ulvik, M. Veiledning av Nye Lxrere. Nasjonale og Internasjonale Perspektiver; Universitetsforlaget: Oslo, Norway, 2018.

8. Lejonberg, E. Hvordan påvirker veilederutdanningene utøvelse av veilederrollen? En analyse av forventinger uttrykt i styringsdokumenter, forskning og faglitteratur. Nord. Nord. Tidsskr. Veil. Pedagog. 2019, 4, 1-16. [CrossRef]

9. Eik, L.-T. Ny i Profesjonen. En Observasjons-og Intervjustudie av Førskolelæreres Videre Kvalifisering Det Første Året i Yrket. Ph.D. Dissertation, University of Oslo, Oslo, Norway, 2014.

10. Klages, W.; Lundestad, M.; Sundar, P. Mentoring of newly qualified teachers in early childhood education and care centres: Individual or organizational orientation? Int. J. Mentor. Coach. Educ. 2019, 9, 103-118. [CrossRef]

11. Hansen, F.T. At Stå i Det Åpne. Dannelse Gennem Filosofisk Undren og Nærvær; Hans Reitzels Forlag: Copenhagen, Danmark, 2008.

12. Moxnes, A.R. Refleksjon i barnehagelærerutdanningen. Tidsskr. Nord. Barnehageforsk. 2016, 12. [CrossRef]

13. Søndenå, K.; Gradovski, M. Pre-teksten sin rolle i rettleiing av nyutdanna profesjonsutøvarar-ei kronotopisk analyse. Uniped 2017, 40, 374-385. [CrossRef]

14. Reinertsen, A.B. Veiledningsaktivisme. Å tenke med funksjon, forskjell og fiksjon. In Tillit, Tenkning og Trøbbel i Profesjonsveiledning; Larsen, A.S., Luthen, G., Ulla, B., Eds.; Gyldendal: Oslo, Norway, 2021; pp. 257-276.

15. Larsen, A.S. Når vanskeligheter vernes om og ønskes velkommen. Kognit. Pædagog. Tidsskr. Gode Læringsmiljøer 2017, 106, $32-45$.

16. Larsen, A.S.; Ulla, B. Tillit med besvær. In Tillit, Tenkning og Trøbbel i Profesjonsveiledning; Larsen, A.S., Luthen, G., Ulla, B., Eds.; Gyldendal: Oslo, Norway, 2021; pp. 29-52.

17. Ulla, B.; Larsen, A.S. Misforståelser og trøbbel-en utvidet oppmerksomhet mot veiledningsfaglige grunnproblematikker. In Tillit, Tenkning og Trøbbel i Profesjonsveiledning; Larsen, A.S., Luthen, G., Ulla, B., Eds.; Gyldendal: Oslo, Norway, 2021; pp. 299-320.

18. Nuttall, J.; Thomas, L. Time and temporality in early childhood educators' work. Eur. Early Child. Educ. Res. J. 2015, 23, 512-523. [CrossRef]

19. Grosz, E. The Nick of Time: Politics, Evolution, and the Untimely; Duke University Press: Durham, NC, USA, 2004.

20. Moxnes, A.R. Sensing, Thinking and Doing Reflection in Early Childhood Teacher Education. Ph.D. Dissertation, University of South-Eastern Norway, Drammen, Norway, 2019.

21. Dahlberg, G. Pedagogy as a loci of an ethics of an encounter. In Governing Children, Families and Education: Restructuring the Welfare State; Bloch, M.N., Holmlund, K., Moqvist, I., Popkewitz, T., Eds.; Palgrave Macmillan: New York, NY, USA, 2003; pp. 261-286.

22. McCumber, J. Time and Philosophy: A History of Continental Thought; McGill-Queen's University Press: Montreéal, QC, Canada, 2011.

23. Ministry of Education and Research. Veiledning av Nyutdannede Nytilsatte Lærere i Barnehage og Skole [Mentoring Newly Qualified Teachers in Kindergartens, School and Upper Secondary Education]; Ministry of Education and Research: Oslo, Norway, 2018. 
24. Braidotti, R. Writing as a nomadic subject. Comp. Crit. Stud. 2014, 11, 163-184. [CrossRef]

25. Braidotti, R. A theoretical framework of the critical posthumanities. Theory Cult. Soc. 2018, 36, 31-61. [CrossRef]

26. Derrida, J. Of Grammatology; John Hopkins University: Baltimore, MA, USA, 1976.

27. Hoy, D.C. The Time of Our Lives: A Critical History of Temporality; MIT: Cambridge, MA, USA, 2009.

28. Grosz, E. Time Travels: Feminism, Nature, Power; Duke University Press: Durham, NC, USA, 2005.

29. Alhadeff-Jones, M. Time and the Rhythms of Emancipatory Education: Rethinking the Temporal Complexity of Self and Society; Routledge: London, UK, 2017.

30. Dufourmantelle, A. Praise of RISK; Miller, S., Translator; Fordham University Press: New York, NY, USA, 2019. 